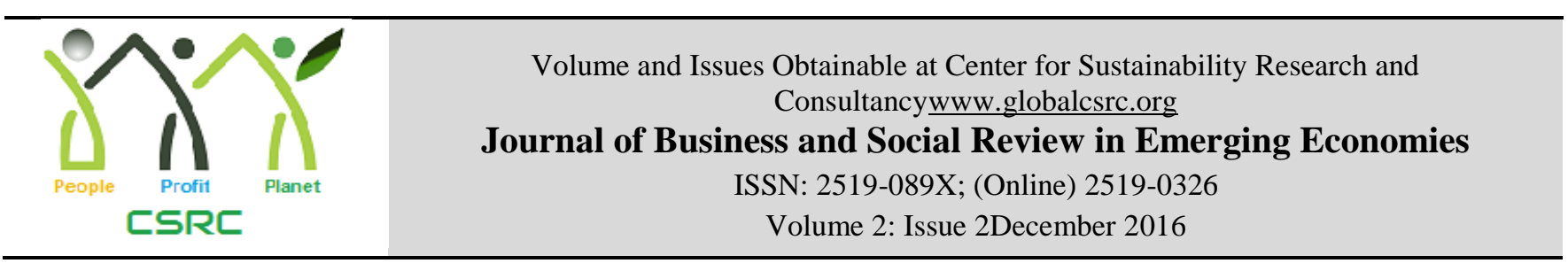

\title{
The Role of Subjective Culture on Consumer Perception towards Service Quality Delivery
}

\author{
${ }^{1}$ Tiara Turay \\ Lecturer at University Dharma Andalas Padang, Indonesia, \\ tiaragf2@gmail.com
}

\begin{tabular}{l}
\hline ARTICLEDETAILS \\
\hline History \\
Revised format: Nov 2016 \\
AvailableOnline: Dec 2016 \\
\\
\hline Keywords \\
Subjective Culture \\
Consumer Perception \\
Service Quality \\
\hline
\end{tabular}

\section{JEL Classification:} D11,D19,139

\begin{abstract}
Objective: The purpose of this paper is to describe the role of subjective culture in influencing the relationship between service quality and consumer perception. Theoretical framework of this conceptual paper developed based on The Rater Model by relating the model with Subjective culture

Methodology:This research is a conceptual paper. The secondary data research was conducted to support this study. The data were gathered from the valuable resources such as articles, books, and on-line information. This paper is aimed to describe how subjective culture holds the crucial role in shaping consumer perception toward service quality delivery.

Results: Through the empirical research analysis, it was resulted that the subjective culture plays theimportant role in shaping consumer perception toward the service quality delivery.

Implication: This research contributes to knowledge and increases the understanding of existing literature on Subjective culture, service quality, and consumer perception. This research is expected can be used for additional refference to academicians and practitioners by fully understanding that consumer perception is closely connected with subjective assessment which are influenced by consumers' belief, attitude, norm, roles, task, values (the elements of subjective culture ). By having deep understanding about the effect of subjective culture on perception of the consumer toward the quality of service delivery, it will enable the organization to design service quality standard that match with consumers' demand in based on their background and expectation.
\end{abstract}

(C) 2016 The authors, under a Creative Commons AttributionNonCommercial 4.0

\section{Introduction}

Satisfaction is closely related to perception. Consumer satisfaction itself in fact is consumer perception (Parasuraman, 1988). Consumer perception hold the critical point when it comes into evaluation of

*Corresponding author's email address: tiaragf2@gmail.com

Recommended citation: Turay, T. (2016). The Role of Subjective Culture on Consumer PerceptionTowards Service Quality Delivery. Journal of Business and Social Review in Emerging Economies,2(2)175-188. DOI:

https://doi.org/10.26710/jbsee.v2i2.34 
service in term of the customer expected and perceived service. Service quality y has been a centre focused for academicians and practices especially when Parasuraman, Zeithaml\& Berry (1985) brought this topic in their research. In service marketing's area, service quality plays central role in the process of understanding customer satisfaction and retention (Parasuraman, Zeithaml, \& Berry 1988). In service industry, quality is as a variable that has important roles (Yusoff\& Ismail, 2008). In the past researched of Sumaedi, Bakti\&Metasari (2011), Abousi\&Atinga (2011), proved that service quality is as an important factor in determining satisfaction.

Remembering the important of service quality in building customer satisfaction, therefore the service provider is expected to understand this process by looking at the customer generational differences, life stage. Those backgorud of the consumers can influence their preferences for service as well as culture, sub culture, and subjective culture (Zeithaml, Bitner\&Gramler, 2009). Accordingly, it will be valuable for the organizations to have strong knowledge on patients' cultural background, especially subjective culture in order to meet consumers' service standard.

Culture plays important part in developing perception process itself. The main reason behind a person's desire or determination is culture (Kotler,2000). Those statements indicate that culture plays the important role in shaping consumers behavior. People from different culture have different behaviour toward their expectation, perception and lifestyle that make differences in their consumption and judgement of a product or service.

Shavitt\&Torelli,(2009) mentioned that culture consists of combining factors that generate perception, evaluation, communication, and action among people who share knowledge, geographic location, and language - Accordingly, Zeithaml, Bitner\&Gramler (2002) mentioned that there is a connection between consumers' perceptions of serviceand culture. Therefore, People who come from different culture have their own way in interpreting, selecting, and organizing the stimuli that they received. So it is happened commonly that culture often lead to misunderstanding. For example, in China, white colour represents the unhappiness, bad luck and mourning (Kegan, 2015) while in Indonesia, white colour is as the representation of purity and holiness.

Parasuramanet al. (1988) had established SERVQUAL as a framework of service quality measurement. Here, cultural factor had not been included as the factor that influences consumer perception. However, Winsted (1999) believed that it was important to include culture as one of the factors that influence service quality. The reason why Winsted insisted to include culture as one of the important factors that determine consumer's perception it was because Winsted had conducted studied on two cultures such as: Japan and U.S. The purpose of Winsted study was to examine how cultural differences had effect on customers' service quality evaluation. Winsted proposed the dimensions of service quality such as; authenticity, caring, perceived control, courtesy, formality, friendliness, personalization, and promptness. Through the study, Winsted found that there were some similarities and differences between Japanese and American cultures in shaping perception. Accordingly Winsted conclude that it was important to adapt and utilize culture as one of important factor in designing appropriate service. In highlighting the crucial contribution of service quality toward customer satisfaction, therefore, service provider is expected to understand this process by looking at the customer generational differences, life stage that can influence their preferences for service as well as culture, sub culture, and subjective culture (Zeithaml, Bitner\&Gramler, 2009).

Many previous studies had been done related to the influence of culture on customer perception. Many scholars had shared the same viewed that perception were actually varies depend on the culture (Ramez, 2008), Bhang,Beatty,Walsh(2008),Triandis(2002),Furrer,Liu,Sudharsan(2000),Mattila(2000)).Voyer 
and kastanakis (2013) in their research on the effect of culture on perception and cognition, the authors had addressed the gap in cross-cultural consumer behaviour by providing a depth review and analysis regarding to the effects of culture on pre-behavioural processes. The pre-behavioural process is known as perception and cognition.

Zhang and Walsh (2008) had gave future direction and suggestion to go beyond Hofstede in doing consumer service research. Both authors believed that it was critical to think about the other cultural value dimension in conducting cultural research for instance, the cultural work of Triandis, Scwartz and Hall. By applying the other aspect of cultural approach it could be used to understand customer deeply. The authors also believed that by using these different components of culture (value and belief systems, communication systems, and material culture) the essence of culture and its impact on consumer service experienced would be captured.

Bond (2002) mentioned that Hofstede nation-level of culture dimension such as individualism, power distance, uncertainty avoidance, masculinity, long-term orientation, were conceptually, empirically, were quite different from individual culture value. The conceptual and measures of nation-level culture of all the citizens of a country may not share similar cultural characteristic. Bond suggestion had also supported by Voyer and kastanakis (2013). Both authors believed that the researchers should be more focused on examining the effect of culture at the individual level rather than broad cross-cultural difference such collectivism/individualism (Voyer\&Kastanakis, 2013).

Accordingly, in this paper, the writer brings the Subjective Culture as the variable that can give the effect on relationship between service quality and consumers' perception to involving of Subjective culture in socio-psychological factor is still rare in research (Genkova, 2009). The important in adopting subjective culture for understanding consumer perception in service context is because subjective culture has the ability to influence consumer's perception. Subjective culture itself, describes as the way, how people experience their culture and how this affects their behavioural pattern (Triandis, 1994).

\section{Literature review}

\subsection{Consumer Perception}

The crucial part of consumer's perception is in the part of perception itself. Perception is tightly related to satisfaction. Consumer's satisfaction is actually as the result from consumer's perception. On the other words, consumer perception is actually consumer satisfaction (Parasuraman, 1988)

In Service quality, consumer's perception can be defined as subjective assessments of actual service experience

(Zeithmal, Bitner, Gramler,2009). Accordingly, perceived quality of service quality is as the consumer's judgment toward overall excellence service (zeithmal 1987: Parasuraman, Zethmal, Berry 1988).

Consumer perception, according to Schiffman and kanuk (2009) is as the process which individuals select, organize, and interpret stimuli into a meaningful and coherent picture of the world. Perception became a strategyfor marketers because consumers make decision based on their perception.

As it shown in figure 2.3, perceived quality is a part of customer satisfaction since service quality is concentrated on dimensionsof service. Whereas, satisfaction is influenced by perception of service quality, product quality, and price, as well as with situational factors and personal factors (Parasuraman et al, 1988). 


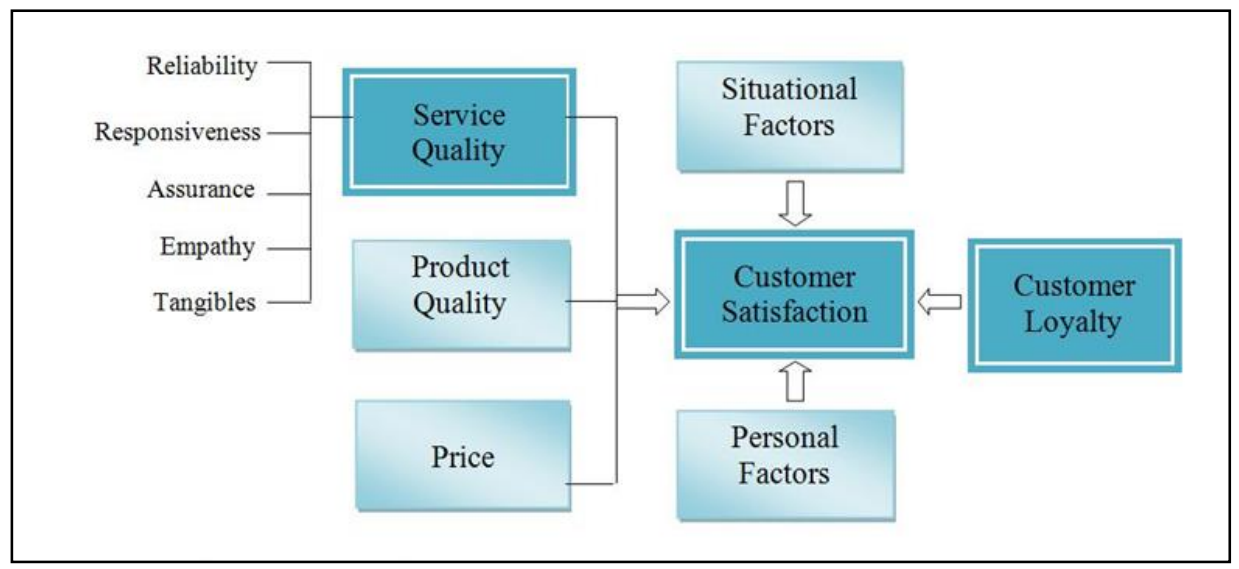

Figure 2.3 Customer Perceptions OfQuality And Customer Satisfaction Source: Parasuraman et al (1988)

In retaliation on Figure 2.3, Parasuraman,Zeithaml\&Berry (1988)explained thatservice quality concernon evaluation of service that give the impact on customer's perception. The five dimension of service quality that becomes the critical points of evaluation are reliability, assurance, responsiveness, emphathy and tangibles. While Satisfaction, is influence by perceptions of service quality, product quality, and price, as well as situational factors and personal factors.

\subsection{Service Quality}

The research on Service quality has been an interesting subject of discussion for more than the last two decades. The interesting part of service quality is the abstract concept service which makes service quality as a complex subject. It is not easy to be measured service quality. The difficulties of measuring service quality are due to the changes of individual preferences. The changing of individual preferences is as the result of time changing (Saurina\&Coenders, 2002).

Service quality is as a key to success for a firm in differentiating itself from competitors (Jamal \&Anastasiadou, 2009). Several studies had proved that good service quality leads to the customer retention and the attraction, reduced costs, build corporate image, positive word-of-mouth recommendation, and profitability (Cronin , Brady \&Hult, 2000; Kang \& James, 2004; Yoon \& Suh, 2004).

Service quality is defined as customer's perception of how well a service meets or exceeds their expectation

( Zeithamal,Parasuraman,\& Berry,1990). Service quality is alsoas critical element of customer perceptions that link customer satisfaction and become the significant elements in customer's evaluation of service (Zeithmal, Bitner, \& Gremler, 2009). The importance of Service quality is when it comes in measuring customer satisfaction by matching their perception with expectation of service quality. SERVQUAL measurement become a tool that remains the most complete attempt to conceptualize and measure service quality (Zeithaml et al., 2009).

The purpose of designing SERVQUAL scale as Schiffman\& Kanuk (2010) explained that the SERVQUAL scale was to measure the gap between customer's expectations and perceptions of the actual service delivery by referring to five dimensions of SERVQUAL. In addition, SERVQUAL it is an 
efficient model in helping an organizationin bridging the gap between perceived and expected service.

In 1985, Parasuraman had identified 97 items with spread all over the 10 dimensions on service quality. However, Parasuraman, Zeithaml\& Berry (1988) had conducted data collection and scale purification on the 97items attributes. It resulted that the 97 items were reduced to 22 items located among five dimensions of service quality. These five dimensions of service quality are: tangible, responsiveness, empathy, assurance and reliability. The SERVQUAL model then transformed into five dimensions. The five dimensions of SERVQUAL as the representation of the important dimensions in customers' eyes. The five dimensions of service quality are as reference point of customers' perception. (Please see Table 2.2)

SERVQUAL's Five Dimension

\begin{tabular}{|l|l|}
\hline SERVQUAL DIMENSION & Description \\
\hline Reliability & $\begin{array}{l}\text { The ability of service provider to perform the promised } \\
\text { service dependably and accurately. }\end{array}$ \\
\hline Assurance & $\begin{array}{l}\text { The employees' Knowledge and courtesy; their ability } \\
\text { inspire trust and confidence. }\end{array}$ \\
\hline Tangibles & $\begin{array}{l}\text { appearance of physical facilities, equipment,personnel } \\
\text { and writtenmaterials. }\end{array}$ \\
\hline Empathy & Caring, individualized attention given to customers. \\
\hline Responsiveness & $\begin{array}{l}\text { The employees have willingness to help customer and } \\
\text { provide prompt service. }\end{array}$ \\
\hline
\end{tabular}

Parasuraman ,Zeithaml and Berry (1988).

The fivedimension of Service Quality are composed by two groups: the first group is the outcome dimension. Outcome dimension is focusedon the reliable delivery of the core service. The second group is the process dimension. The process dimension focuses on how core service is delivered (employees' responsiveness, assurance, and emphaty in handling customers) and the service tangible aspects ( Schiffman and Kanuk, 2010)

Figure 2.3 captured RATER model. The five dimensions of service quality are believed to be the core criteria of customers' evaluation of service quality. Customers' evaluation of service is based on their expectations and the customers' perception of service quality. Accordingly, Berry, Zeithaml and Parasuraman (1985) added that the connection between customer's expected service and attributes that directly affect customer's expectations. The attributes of customer expectations are word of mouth advertising, personal needs, past experiences, and external communications

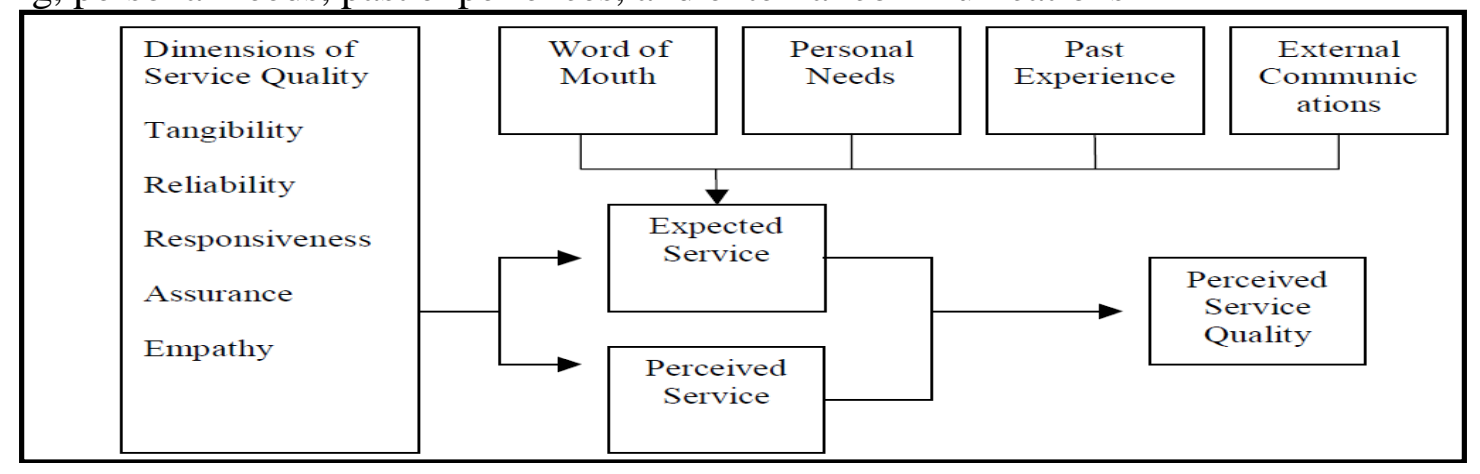




\section{Figure 2. 1Rater Model}

Zeithaml, Parasuraman\& Berry, 1985

The Service quality model pictures a comprehensive conceptualization of service quality with an instrument to measure perceived service quality (Amin \& Isa, 2008). Afterward, SERVQUAL is a wellknown model for academics and practices to assess the customer perception of service quality for a variety of service industries. The applications of SERVQUAL have been tested and used to measure quality of service in different service sector, such as in banking sector (Poolthong\& Mandhachitara,2009), hospitality sectors (Nadir \& Hussain, 2005), airline service(Sultan \&Simpson,2000), health care services (Baker,Akgun\&Assaf , 2008; Aagja\& Garg, 2010; Untachai (2013).

\subsection{Subjective Culture}

Subjective culture is a physiological construct (Petia, 2009), it describes the way, and how the culture affects behavioural patterns of the people who share and experiences the same culture (Triandis, 1994).Triandis developed a model of subjective culture that related with social behavior He believed that this model was potential to be adapted with consumer behavior concept. This model brings the psychology as the process that intervene the links between cultures and social behavior. Subjective culture itself, represent the categorizations, associations, norms, roles, and values in a culture (Triandis, 1994). Subjective culture is reflected by the individual's perception of the elements of the culture system (Dorfman and Howell, 1988). Straub, Evaristo, Karahanna, \&Srite (2002) stated that culture can reveal itself at different perceived or Subjective culture.

Triandis (1994) constructed a model of subjective culture which he related with social behaviour concept. He believed that this model was a good model to be adapted in consumer behaviour domain. This model highlighted the psychology as the process that intervene the links between cultures to social behaviour. Subjective culture represents the categorizations, associations, norms, roles, and values in a culture (Triandis, 1994). Subjective culture is reflected by the individual's perception of the elements of the culture system (Dorfman and Howell, 1988). Straub, Evaristo, Karahanna, \&Srite (2002) stated that culture can reveal itself at different perceived or Subjective culture. Subjective culture itself composed by the elements that link the pattern of action and values. The element of Subjective culture is: categories, association, beliefs, attitudes, norms, roles, tasks, values, and value orientation (Triandis, 2002).

\section{Hypotheses}

Service quality is as one of the determinant factor for success of every organization, including for organization that deal in service sector. The important aspect of service quality is service quality has direct influence on customer satisfaction and perception (Alrubaiee\&Alkaa'ida, 2011). Furthermore, perceived service quality is also had the great ability in impacting customer loyalty and word-of-mouth (Andaleeb, 2001). Because of that, to improve the service quality of an organization, the perception on service quality must always be considered.

Service quality is grounded on the idea that the quality is consumers' subjective assessment toward service delivery. Consumers' perception of service quality are closely relied on the size and direction of the distance that lies between customers expectation to receive and perceived service (Kumar et al., 2009).

Hypothesis 1: Service Quality has direct impact on Consumer's Perception. 
There were some studies that investigated the connection between the service quality and culture. Many past researchers found that the consumers perceptions of service quality are vary between one country and another. Service providers need to be culturally aware toward the consumers wants and need of service encounter (Bang,Taylor\& Moon2005; Donthu\&Yoo, 1998; Malhotra, Ulgado, Agarwal, Shainesh\& $\mathrm{Wu}, 2005)$. Culture play the important role in understanding why people's behaviour can be difference across cultures ( Kanastakis\&Voyer, 2014) Since service quality is also can be defined as consumer perception (Zeithmal et al.,1990). In connection between subjective culture and perception, Zeithmal et al (2009) mentioned that perception is as subjective assessment which influence by the subjective side of the customers.

Throughout the study on the relationship between culture and service quality perception, Furrer, et all (2000) found that consumers' perception of service quality are varies depend on a cultural group. Culture is attached into person's lives and culture also influences the decisions making process. In addition, culture is not only influences people' behaviour, but it also give the effects on the rationalization process (Patterson \&Mattila, 2008). It can be said that, culture shapes people's perception of service quality $(\mathrm{Seo}, 2012)$

Subjective Culture is became the background of subjective assessment consumer perception. As was cited by Schiffman and kanuk (2010) in the relationship between culture and consumer perception, "Consumer both view themselves in the context of culture and react to their environment based upon the cultural framework that they bring to that experience. Based on the explanation before came up the reason why people perceive the world through their own cultural point a view" (Ueltschy and Krampf (2001). The subjective side of the consumer is what as the element of subjective culture such as; belief, norms, roles, tasks, values, and value orientation. (Triandis, 2002).

Hypothesis 2: Subjective Culture influences the relationship between service quality and consumer's perception.

\section{Methodology}

This paper is a conceptual paper that aimed to analyze the influence of subjective culture on service quality perception. In this study the writer conducting the secondary data research as the based for analyzing the links between variables. The objective of this conceptual paper is to examine the effect of Subjective culture on the relationship between service quality and consumer's perception. In this research, secondary data such as journals, articles, books were gathered thorough library research and on line service.

\section{Conclusion and Recommendation}

In this highly competitive business environment, quality has become one of important aspect for all business sectors, including service sector.Providing high service quality to customers, enable a firm to differentiate it and gain a competitive advantage in the market (Wang, Lo \& Hui, 2003). Now a day service quality becomes the differentiator in the marketplace. Service quality among the most critical aspects for the strategic management of firms (Ekinci et al. 2003)

Subjective culture is one of the refference pointfactor that can influence the customer in accepting or rejectingto use a service. The limitation of understanding the segmentation Culture of where the organization operates will also lead to the failure of the organizations to deliver the service that match with consumer inquiries. This statement of the problem derived from one of the service gaps from Parasuraman (1988), Parasuramanet all.(1985) develop the Service Quality Gap Model to identify and 
analyze gaps between expected and perceived service of service performance.

In retaliation with this paper, one of the reasons of the occurrence of customer dissatisfaction is because of the lack knowledge of consumer cultural back ground such as demographic, psychographic, gender, and culture and subjective culture. The limitation of understanding of those factors lead to the failure of the organization management to deliver the service that match Consumers demand, referring to the variations of consumer perception of service quality in cultural differences, as well as remembering the important connection between subjective culture and Consumer Perception on service Quality.

In conclusion, it is important for the organization to learn about its consumer's interm of their subjective culture such as belief, values, custom, religion, roles, tasks, and values. that shape the behaviour on consumption and evaluation of service. In this research, subjective culture is proposed has the ability to influence the relationship between consumer's perceptions and service quality.

\section{References}

Abuosi, A. A., \&Atinga, R. A. (2013). Service quality in healthcare institutions: establishing the gaps for policy action. International journal of health care quality assurance, 26(5), 481-492.

Aagja, J. P., \& Garg, R. (2010). Measuring perceived service quality for public hospitals (PubHosQual) in the Indian context. International Journal of Pharmaceutical and Healthcare Marketing, 4(1), 60-83.

Alrubaieelaith, Alkaa'idaFerass (2011),The Mediating Effect OF Patient Satisfaction In the Patient's Perception Of Healthcare Quality - Patient Trust Relationship,International Journal of Marketing StudiesISSN 1918-719X, E-SSN 1918-7203, Vol.3, No.1:

Aljoudimi .Y.I, B. Rejab,Zulkiflee Bin Muhamed (2015) International Journal of Managerial Studies and Research (IJMSR) Volume 3, Issue 6, June 2015, PP 97-116 ISSN 2349-0330 (Print) \& ISSN 2349-0349 (Online) www.arcjournals

Alshaibani, E., \&Bakir, A. (2016). A reading in cross-cultural service encounter: Exploring the relationship between cultural intelligence, employee performance and service quality. Tourism and Hospitality Research, 1467358416651474.

Amin, M., \& Isa, Z. (2008). An examination of the relationship between service quality perception and customer satisfaction: A SEM approach towards Malaysian Islamic banking. International Journal of Islamic and Middle Eastern Finance and Management, 1(3), 191-209.

Andaleeb,S.S (2001), Service Quality Perception and Patient Satisfaction: a Study of Hospital in Developing Country. Social Science medicine,52,pp.135-1370

Akbar, M. M., \&Parvez, N. (2009). Impact of service quality, trust, and customer satisfaction on customers loyalty. ABAC Journal, 29(1).

Anbori, A., Ghani, S. N., Yadav, H., Daher, A. M., \& Su, T. T. (2010). Patient satisfaction and loyalty to the private hospitals in Sana'a, Yemen.International Journal for Quality in Health Care, 22(4), 310-315.

Babin .Zikmund, Griffin Carr (2010) BUSINESS MARKET RESEARCH, $8^{\text {th }}$ edition, SouthWestern/Cengage Learning

Bakar, C., Akgůn, S.H. \& Al Assaf, A.F. (2008) "The role of expectations in patient assessments of hospital care: An example from a university hospital network, Turkey," International Journal of Health Care Quality Assurance, vol. 21(4), p. 343-355

Baumgartner, H., \& Homburg, C. (1996). Applications of structural equation modeling in marketing and consumer research: A review. International journal of Research in Marketing, 13(2), 139-161.

Bang, H.K., Raymond, M.A., Taylor, C.R. and Moon, Y.S., 2005. A comparison of service quality dimensions conveyed in advertisements for service providers in the USA and Korea. 
International Marketing Review, 22(3), pp. 309-326.

Berry, L. L., Parasuraman, A., \&Zeithaml, V. A. (1994). Improving service quality in America: lessons learned. The Academy of Management Executive, 8(2), 32-45.

Bloem, S., \&Stalpers, J. (2012). Subjective Experienced Health as a Driver of Health Care Behavior. Nyenrode Research Paper Series, (12-01).

Bond, M. H. (2005, March). A cultural-psychological model for explaining differences in social behavior: Positioning the belief construct. In Culture and social behavior: The Ontario symposium (Vol. 10, p. 31). Psychology Press.

Bungin,Burhan, (2005),MetodologyPenlitianKuantitatif, EdisiPertama, ISBN,2005

Butt, M. M., \& de Run, E. C. (2011). Do target and non-target ethnic group adolescents process advertisements differently?. Australasian Marketing Journal (AMJ), 19(2), 77-84.

Bloem, S., \&Stalpers, J. (2012). Subjective Experienced Health as a Driver of Health Care Behavior. Nyenrode Research Paper Series, (12-01).

Bollen KA. Structural Equations with Latent Variables. New York, NY: Wiley; 1989

Bond, M.H (2002) Reclaiming the individual from Hofstede's ecological analysis--A 20-year odyssey: Comment on Oyserman et al. (2002). Psychological Bulletin, Vol 128(1), Jan 2002, 73 77. http://dx.doi.org/10.1037/0033-2909.128.1.73

Brady, M. K., \& Cronin Jr, J. J. (2001). Some new thoughts on conceptualizing perceived service quality: a hierarchical approach. Journal of marketing, 65(3), 34-49.

Brown, S.W., \& Bond, E.U. III (1995). The internal/external framework and service quality: Toward theory in services marketing. Journal of Marketing Management, 19(4), 49-67

Cao, T. K., \& Phan, T. T. H. (2015). Cultural Influences on Overall Service Quality Expectations: Evidence from Vietnamese Customers. Asian Social Science, 11(25), 151.

Carrillat, F. A., Jaramillo, F., \&Mulki, J. P. (2007). The validity of the SERVQUAL and SERVPERF scales: A meta-analytic view of 17 years of research across five continents. International Journal of Service Industry Management, 18(5), 472-490.

Chaniotakis, I. E., \&Lymperopoulos, C. (2009). Service quality effect on satisfaction and word of mouth in the health care industry. Managing Service Quality: An International Journal, 19(2), 229-242.

Cook, L. S., \&Verma, R. (2002). Exploring the linkages between quality system, service quality, and performance excellence: service providers' perspectives. Quality Management Journal, 9(2), 4456.

Curry, A.C. and Stark, S. (2000), "Quality of service in nursing homes”, Health Services

Cronin, J. J., Brady, M. K., \&Hult, G. T. M. (2000). Assessing the effects of quality, value, and customer satisfaction on consumer behavioral intentions in service environments. Journal of retailing, 76(2), 193-218.Management Research, Vol. 13, pp. 205-15.

Dasanayaka, S. W. S. B., Gunasekera, G. S. P., \&Sardana, G. D. (2012). Quality of healthcare service delivery in public sector hospitals: a case study based on Western Province in Sri Lanka. World Review of Entrepreneurship, Management and Sustainable Development, 8(2), 148-164.

Dey, P. K., Hariharan, S., \& Brookes, N. (2006). Managing healthcare quality using logical framework analysis. Managing Service Quality: An International Journal, 16(2), 203-222.

Donthu, N. And Yoo, B., 1998. Cultural influences on service quality expectations. Journal of Service Research, 1(2), pp. 178-186.

Donabedian, A. (2005). Evaluating the quality of medical care. Milbank Quarterly, 83(4), 691-729.

Duggirala, M., Rajendran, C., \&Anantharaman, R. N. (2008). Patient-perceived dimensions of total quality service in healthcare. Benchmarking: An International Journal, 15(5), 560-583.

E. Grigoroudis and Y. Siskos (2010) Customer Satisfaction Evaluation. Methods for

Measuring and Implementing Service Quality. International Series in Operations Research \& Management Science vol. 139: Springer 
Ekinci, Yuksel, PopiProkopaki, and CihanCobanoglu (2003), "Service quality in

Cretan accommodations: Marketing strategies for the UK holiday market," International Journal of Hospitality Management, 22 (1), 47-66.

Fitriati, R., \&Rahmayanti, K. P. (2012). Government support in Triple Helix Collaboration to provide health service delivery: case study government hospital in Bengkulu Hospital. Procedia-Social and Behavioral Sciences, 52, 160-167.

Furrer, O.,Liu,B.SC., and Sudharsan,D.(2000). The Relationship Between Culture and Service Quality Perception. Journal of Service Research, Vol.2 No .4,pp.355-71

Gayatri, G., Hume, M., \& Sullivan Mort, G. (2011). The role of Islamic culture in service quality research. Asian Journal on Quality, 12(1), 35-53.

Ghotbabadi, A. R., Feiz, S., \&Baharun, R. (2015). Service Quality Measurements: A Review. International Journal of Academic Research in Business and Social Sciences, 5(2), 267.

Grönroos, C. (1984). A service quality model and its marketing implications.European Journal of marketing, 18(4), 36-44.

Hofstede, G. H., \& Hofstede, G. (2001). Culture's consequences: Comparing values, behaviors, institutions and organizations across nations. Sage.

Houle, D., \& Fleece, J. (2012). Why one-third of hospitals will close by 2020.KevinMD. com, March, 14.

Hong, Y. Y., Morris, M. W., Chiu, C. Y., \& Benet-Martinez, V. (2000). Multicultural minds: A dynamic constructivist approach to culture and cognition. American psychologist, 55(7), 709.

Isik, O., Tengilimoglu, D., \&Akbolat, M. (2011). Measuring health care quality with the Servqual method: a comparison in public and private hospitals. HealthMED, 5(6), 1921-1930.

Jain, S. K. \& Gupta, G. (2004). Measuring Service Quality: SERVQUAL vs. SERVPERF Scales. VIKALPA, 29(2), 25-37.

Jamal, A., \&Anastasiadou, K. (2009). Investigating the effects of service quality dimensions and expertise on loyalty. European Journal of Marketing,43(3/4), 398-420.

Kastanakis, M. N., \&Voyer, B. G. (2014). The effect of culture on perception and cognition: A conceptual framework. Journal of Business Research,67(4), 425-433.

Karassavidou, E., Glaveli, N., \&Papadoupoulos, C.T. (2009). Quality in NHS hospitals: no one knows better than patients. Measuring Business Excellence, 12(1), 34-46.

Kesuma, I. A. W., Hadiwidjojo, D., Wiagustini, N. L. P., \&Rohman, F. (2013). Service Quality Influence on Patient Loyalty: Customer Relationship Management as Mediation Variable (Study on Private Hospital Industry in Denpasar). International Journal of Business and Commerce, 2(12), 1-14.

Kitapci, O., Akdogan, C. and Dortyol, I.T. (2014) 'The impact of SQ dimensions on patientsatisfaction, repurchase intentions and word-of-mouth communication in the public healthcare industry', Procedia-Social and Behavioral Sciences, Vol. 148, No. 1, pp.161-169.

Keegan, Warren J. Global marketing (2013) $7^{\text {th }}$ Edition,Pearson Education, Inc., public

Kline, R. B. (2010). Principles and practice of structural equation modeling (3rd ed.). New York, New York: Guilford Press

Kluckhohn, Clyde K. (1951), "Values and value orientations in the theory of action," in Toward a General Theory of Action, T. Parsons and E. Shils, eds., Cambridge, MA: Harvard University Press.

Kroeber, A. L., \&Kluckhohn, C. (1952). Culture: A critical review of concepts and definitions. Papers. Peabody Museum of Archaeology \& Ethnology, Harvard University.

Kotler, P., \& Keller, K. (2012). Marketing management 14th edition. Prentice Hall.shing as Prentice Hall 
Kotler. P and Armstrong. G, (2001) Principles of Marketing, Prentice hall, Inc

Kumar, M., Kee, F.T., \&Manshor, A.T. (2009). Determining the relative importance of critical factors in delivering service quality of banks: An application of dominance analysis in SERVQUAL model. Managing Service Quality, 19(2), 211-228 Kuo, Y., Wu, C., \& Deng, W.

Lim PC, Tang NKH: A study of patients' expectations and satisfaction in Singapore hospitals. Int J Health Care Qual Assur. 2000, 13: 290-299. 10.1108/09526860010378735.

MacKinnon, D. P. (2008). Introduction to Statistical Mediation Analysis. New York: Erlbau

Martin Reimmann, Ulrich F.Lunemann and Richard Chase (2008). Uncertainty Avoidance as a Moderator of the Relationship between Perceived Service Quality and Customer Satisfaction. Journal of Service Research, 11.

Malhotra, N.K., Ulgado, F.M., AgarwalL, J. and Shainesh, G. AND Wu, L., 2005. Dimensions of service quality in developed and developing economies: multi-country cross-cultural comparisons. International Marketing Review, 22(3), pp. 256.

McMullan, R., \& Gilmore, A. (2008). Customer loyalty: an empirical study. European Journal of Marketing, 42(9/10), 1084-1094.

Mangundjaya, W.L.H. (2010). Is There Cultural Change In The National Cultures Of

Indonesia? Paper Presented at International Conference on Association of Cross Cultural Psychology (IACCP), Melbourne, Australia

Mohebifar, R., Hasani, H., Barikani, A., \&Rafiei, S. (2016). Evaluating Service Quality from Patients' Perceptions: Application of Importance-performance Analysis Method. Osong Public Health and Research Perspectives.

Muhammad Butt, M., \& Cyril de Run, E. (2010). Private healthcare quality: applying a SERVQUAL model. International journal of health care quality assurance, 23(7), 658-673

Nadiri, H., \& Hussain, K. (2005). Perceptions of service quality in North Cyprus hotels. International Journal of Contemporary Hospitality Management, 17(6), 469-480.

Nel, D., Heerden, G., Chan, A., Ghazisaeedi, M., Halvorson, W., \& Steyn, P. (2011). Eleven years of scholarly research in the Journal of Services Marketing. Journal of Services Marketing, 25(1), 413

Newman, I. (2008). Mixed methods research: Exploring the interactive continuum. SIU Press.

Patterson, P. G., \&Mattila, A. S. (2008). An examination of the impact of cultural orientation and familiarity in service encounter evaluations.International Journal of Service Industry Management, 19(5), 662-681.

Philip, K. Keller,(2009). Marketing Management, 10th ed., Prentice Hall, Englewood Cliffs, New Jersey: United States of America.

Narang, R. (2011). Determining quality of public health care services in rural India. Clinical Governance: An International Journal, 16(1), 35-49.

Nietzsche, F., \& Ansell-Pearson, K. (1994). Nietzsche:'On the Genealogy of Morality'and Other Writings. Cambridge University Press.

Nketiah-Amponsah, E., \&Hiemenz, U. (2009). Determinants of consumer satisfaction of health care in Ghana: does choice of health care provider matter?. Global journal of health science, 1(2), 50.

Oliver R. L, 1980, "A Cognitive Model of the Antecedentsand Consequences of Satisfaction Decision

Pai, Y. \& Chary, S. (2012). Measuring Hospital Service Quality: A conceptual Framework. In Proceedings of International Conference on Humanities, Economics, and Geography (ICHEG'2012), Bangkok, 17-18 March 2012 (pp. 192-195).

Pakdil F, AydIn O: Expectations and perceptions in airline services: an analysis using weighted SERVQUAL scores. J Air TranspManag. 2007, 13: 229-237. 10.1016/j.jairtraman.2007.04.001.

Parasuraman, A., Zeithaml, Valerie A. \& Berry, Leonard L. (1991) "Refinement and reassessment of the 
SERVQUAL scale," Journal of Retailing, vol. 67(4), p. 420-50

Parasuraman, A., Zeithaml, V.A. and Berry, L.L., (1985) 'A conceptual model of service quality and its implications for future research', Journal of Marketing, Vol. 49, No. 4, pp.41-50.

Parasuraman, A., Zeithaml, V. A., \& Berry, L. L. (1988). Servqual. Journal of retailing, 64(1), 12-40.

Parasuraman, A., Zeithaml, V. A., \& Malhotra, A. (2005). ES-QUAL a multiple-item scale for assessing electronic service quality. Journal of service research, 7(3), 213-233.

Poolthong, Y., \&Mandhachitara, R. (2009). Customer expectations of CSR, perceived service quality and brand effect in Thai retail banking. International Journal of Bank Marketing, 27(6), 408427.

Rakhmawati, Tri, et al. "Developing a service quality measurement model of public health center in Indonesia." Management Science and Engineering 7.2 (2013): 1-15.

Rahman, H. (2016). 'Merantau'-an Informal Entrepreneurial Learning Pattern in the Culture of Minangkabau Tribe in Indonesia.DeReMa (Development Research of Management): JurnalManajemen, 11(1), 15-34.

Ramez, W. S. (2012). Patients' perception of health care quality, satisfaction and behavioral intention: an empirical study in Bahrain. International Journal of Business and Social Science, 3(18).

SaadAndaleeb, S., \& Millet, I. (2010). Service experiences in hospitals in Bangladesh: are there gender inequities?. International journal of health care quality assurance, 23(6), 591-606.

Sanchez-Gutierrez, J., Gonzalez-Uribe, E. G., \&Coton, S. G. H. (2011). Customer satisfaction in the hospitality industry in Guadalajara, Mexico.Journal of Competitiveness Studies, 19(3/4), 17.

Schiffman leon G \&Kanuk Laslie Lazar,(2010), Consumer Bahaviour, Tenth Edition, Pearson, Prentice Hall,Usa

Saurina, C., \&Coenders, G. (2002). Predicting overall service quality: a structural equation modelling approach. (C) Metodološkizvezki, 2002, núm. 18, p. 217-238.

. Schulmeister LK, Mayer K. Quality of life, quality of care and patient satisfaction: perceptions of patients undergoing outpatient autologous stem cell transplantation. OncolNurs Forum 2005 Jan; 32(1):57e67

Schwartz, S. H. (2006). A theory of cultural value orientations: Explication and applications. Comparative sociology, 5(2), 137-182.

Seo, Y. (2012). Cultural impact on customer satisfaction and service quality evaluation in hotels.

Sharma, P. (2010). Measuring personal cultural orientations: scale development and validation. Journal of the Academy of Marketing Science, 38(6), 787-806. http://dx.doi.org/10.1007/s11747-0090184-7

Shavitt, S., Lee, A., \&Torelli, C. (2009). New directions in cross-cultural consumerpsychology. In M. Wänke (Ed.), The social psychology of consumer behavior

(pp. 227-250). New York, NY: Psychology Press

Sheppard, B.H., Hartwick, J. \&Warshaw, P.R. (1988). The theory of reasoned action: A meta-analysis of past research with recommendations for modifications and future research. Journal of Consumer Research, 15, 325-343

Sekaran,Uma (2006) Research Methods For Business,wiley, 2006

Smith, K.B., Humphreys, J.S. and Jones, J.A. (2006), "Essential tips for measuring levels of

consumer satisfaction with rural health service quality", Rural and Remote Health, Vol. 6 No. 4, p. 594.

Straub, D., Loch, K., Evaristo, R., Karahanna, E., \&Srite, M. (2002). Toward a theory-based measurement of culture. Human factors in information systems, 10(1), 61-65.

Sultan, F., \& Simpson Jr, M. C. (2000). International service variants: airline passenger expectations and perceptions of service quality. Journal of services marketing, 14(3), 188-216.

Sumaedi, S., Bakit, I. G. M. Y., \&Metasari, N. (2011). The effect of students' perceived service quality and perceived price on student satisfaction. Management Science and Engineering, 5(1), 88. 
Talib, F., Azam, M., \& Rahman, Z. (2015). Service quality in healthcare establishments: a literature review. International Journal of Behavioural and Healthcare Research, 5(1-2), 1-24.

Tam, J. L. (2007). Linking quality improvement with patient satisfaction: a study of a health service centre. Marketing Intelligence \& Planning, 25(7), 732-745.

Teng, C. I., Ing, C. K., Chang, H. Y., \& Chung, K. P. (2007). Development of service quality scale for surgical hospitalization. Journal of the Formosan Medical Association, 106(6), 475-484

Triandis, H. C., Vassiliou, V., \&Nassiakou, M. (1968). Three cross-cultural studies of subjective culture. Journal of Personality and Social Psychology,8(4p2), 1.

Triandis, H. C. (1994). Theoretical and methodological approaches to the study of collectivism and individualism. CROSS CULTURAL RESEARCH AND METHODOLOGY SERIES-SAGE-, 18(1), 41-41.

Triandis, H. C. (2002). Subjective Culture. Online Readings in Psychology and Culture, 2(2). http://dx.doi.org/10.9707/2307-0919.102

Triandis, H. C. (2006). Cultural aspects of globalization. Journal of International Management, 12(2), 208-217.

Trompenaars, Fons and Charles Hampden-Turner (1997), Riding the Waves of Culture: Understanding Diversity in Global Business. McGraw-Hill.

Untachai, S. (2013). Modeling service quality in hospital as a second order factor, Thailand. ProcediaSocial and Behavioral Sciences, 88, 118-133.

Verma R., \& Boyer K. (2000). Service classifications and management challenges. Journal of Business Strategies, 17(1), 5-24

Wang, Y, Lo, H. and Hui, Y.V. (2003),"The Antecedents of Service Quality and Product Quality and their Influences on Bank Reputation: Evidence from Banking Industry in China", Managing Service Quality,Vol. 1, pp. 72-83.

Winsted, F. K. (1999). Evaluating service encounters: A cross-cultural and cross-industry exploration. Journal of Marketing Theory and Practive, 7(2), 106-123

Yeşilada, F. \&Direktör, E. (2010). Health care service quality: A comparison of public and private hospitals. African Journal of Business Management, 4(6), 962-971

.Zhang, J., Beatty, S. E., \& Walsh, G. (2008). Review and future directions of cross-cultural consumer services research. Journal of Business Research,61(3), 211-224.

Zahari Wan Yusoff, W., Ismail, M., \& Newell, G. (2008). FM-SERVQUAL: a new approach of service quality measurement framework in local authorities.Journal of Corporate Real Estate, 10(2), 130-144

Zeithaml, A, Pasuraman, A., Berry, L. (1990). Delivering Quality Service: Balancing Customer Perceptions and Expectations. New York: The Free Press Division of Macmillan, Inc

Zeithaml VA, Berry LL, Parasuraman A. The nature and determinants of customer expectations of service. J Acad Mark Sci 1993;21(1):1-12.

Zeithaml VA, Bitner MJ, Gremler DD. (2002)Services marketing. New York, NY:McGraw-Hill.

Valarie A. Zeithmal. Mary Jo Bitner. Dwayne D. Gremier (2009) Service Marketing,Fith Edition, McGraw Hill

Zikmund, W. G., Babin, B. J., Carr, J. C., \& Griffin, M. (2013). Business research methods. Cengage Learning.

Zineldin, M., Camgöz-Akdag, H., \&Vasicheva, V. (2011). Measuring, evaluating and improving hospital quality parameters/dimensions-anintegrated healthcare quality approach. International journal of health care quality assurance, 24(8), 654-662. 
